\title{
Trade Openness and Crude Oil Price Effects on Food Inflation: Examining the Romer Hypothesis in Kenya
}

\author{
Caspah Lidiema \\ Corporate Services Division, United Nations Environment Programme (UNEP), Nairobi, Kenya
}

Email address:

lidiema.research@gmail.com

\section{To cite this article:}

Caspah Lidiema. Trade Openness and Crude Oil Price Effects on Food Inflation: Examining the Romer Hypothesis in Kenya. Journal of World Economic Research. Vol. 9, No. 2, 2020, pp. 81-90. doi: 10.11648/j.jwer.20200902.12

Received: May 22, 2020; Accepted: June 8, 2020; Published: June 29, 2020

\begin{abstract}
Food Prices accounts for about 36\% of the overall consumer price index in Kenya and it's the single largest of the 12 components that make up the index. Therefore, shocks in food prices could considerably be transmitted to the overall consumer price index. While Kenya agricultural production is heavily rain-fed, external pressures from and shocks from crude oil price, international trade are transmitted inwards and pile more pressure on food prices as well. While inflation tend to follow all the available information in the market and business per the rational expectations' theory, price factors are a key determinant of business cycles, because price stickiness tend to drive demand. Therefore, demand for food products could be driven by several market features including internal food prices, oil prices, productions and importation costs. The objective of this research was to analyze the effect of Trade openness on food inflation in Kenya with a view of establishing if Romer's hypothesis holds in Kenya. The second objective is to establish the effect of crude oil prices on food inflation in Kenya. The study employed Autoregressive Distributed Lag (ARDL) cointegrating technique to estimate both short-run and long run estimates. The study findings indicate that trade openness significantly has a reducing influence on food inflation hence confirming the existence of Romer's hypothesis in Kenya. Secondly, crude oil prices have a positive and significant effect on food inflation. Interestingly, the study found that money supply does not have significant influence on food inflation. The study recommends embracing and adopting international free trade agreements to further leverage on imports prices, increase buffer storage to cushion against food demand and hence stabilize food prices. Secondly the government should enhance further price controls on oil prices to reduce spillovers to food production and supply costs. In addition, Kenya should develop technologies to improve agricultural farm production to leverage dependence of rain-fed agricultural sector.
\end{abstract}

Keywords: Food Inflation, Trade Openness, Crude Oil, ARDL, Short-run, Long-run, Romer

\section{Introduction and Motivation}

\subsection{Introduction}

Most emerging economies suffer economically due to high inflation levels. In Kenya for instance, inflation rose to up to $20 \%$ in 2012 mostly spearheaded by political temperatures and uncertainty. In addition to changes in macroeconomic policies, inflation is caused by several factors including, increase in income level and money supply; oil prices both at domestic and global level; higher demand domestic good, and sharp rise in international commodities [1, 2]. Inflation computation usually contains, Food and Non-Food components. Food inflation tend to be high and very volatile than Non-Food inflation especially in the emerging and low- income economies [3]. In Kenya for instance, food inflation is about $36 \%$ of the total inflation [4].

While there are, many economic theories (including costpush, demand-pull and the quantity theory of money), that try to decompose and explain the inflation phenomena, inflation has remained to be very dynamic and sophisticated for one theory to entangle. According to the Rational Expectations theory, inflation follows all the available information in the market and the business cycle. However, under the New Neoclassical Synthesis theory, monetary, or demand factors are a key determinant of business cycles, because of price stickiness in the short run [5]. Therefore, theoretically, any efforts by the monetary policy to intervene on inflation usually covers slight elements of the causes of inflation.

Central bank of Kenya (CBK) uses Central Bank Rate 
(CBR) set by the Monetary Policy Committee (MPC) to signal monetary policy stance in a move known monetary targeting technique. the. These targets are set through the monetary policy direction. The rate is raised or lowered depending on the prevailing conditions [6]. The CBK inflation targets is $2.5 \%$ on either side of $5 \%$ mark.

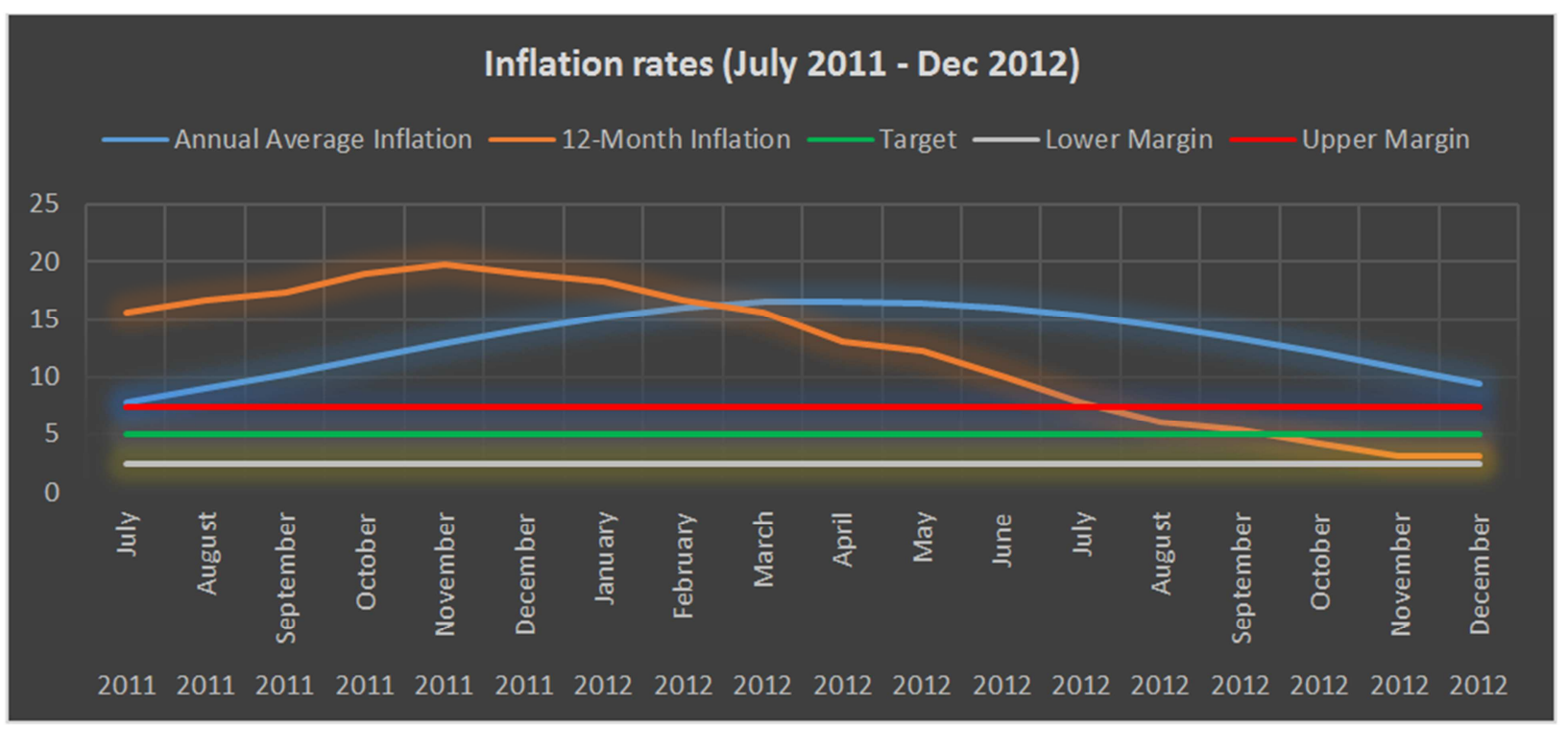

Figure 1. Inflation rates (July 2011 - Dec 2012) Source: CBK.

Between 2011 and 2013, inflation rates in Kenya were above the target bounds and essentially the monetary policy struggled to maintain stability (see Figure 1). However, this was also a period in which there was heightened political temperatures in the country due to what was expected to be high tension-led election and change of political regimes. This change of political sphere in the country was not only expected to affect the governance structure but international trade as well. [7] argued that inflation change of political regimes, cabinet changes and government crises are proxies for political instabilities which leads to high inflation instability.
However, post march elections in 2013 we see (See Figure 2) that domestically Kenya's inflation targets have been almost within the brackets, they have remained largely above the $5 \%$ and sometimes going beyond the upper limit of the CBK's target mostly driven by food inflation. Therefore, this paper concludes that political temperatures in Kenya are usually short-lived and mostly the inflation movements bounces back to the wings of momentary policy and other factors other than political. In fact, [6] opined that inflationary pressure in Kenya in 2011 was mainly due to increase international oil prices and weather-related supply constraints especially reduction in rainfall.

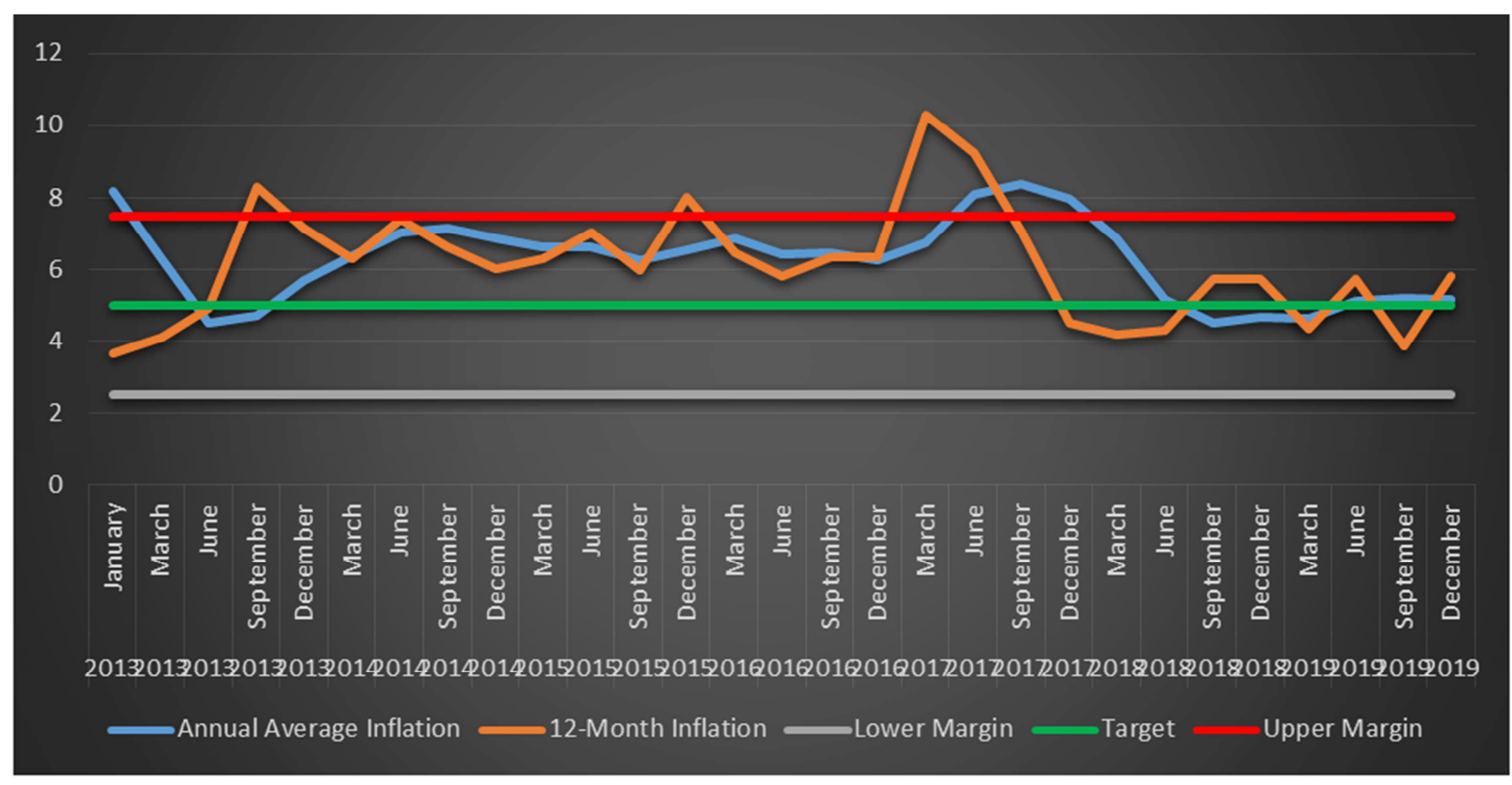

Figure 2. Inflation rates post January 2013 Source: CBK. 
Monetary policies are usually formulated to promotes financial stability through maintaining price stability. Monetary policy in Kenya is put in place by the central bank of Kenya and it involves coordination of various policy instruments. The set of monetary instruments employment will always differ from country to country and region to region. However, while price stability is first and foremost the primary objective of monetary policy, [8] argues that exchange rate stability and the growth of output and employment should not be forgotten as part of the objectives of the monetary policy.
Inflation is affected both domestic and foreign market dynamics. This would include global oil prices; the global financial integration through trade and capital flows. Finck \& Tillmann [9] opines that changes in the inflation process is the ongoing global integration of financial and goods markets. However, they are quick to note that it's not easy to quantify the extent of that effect. Figure 3 clearly indicates that food inflation continues to outshoot non-food inflation and thereby affecting the overall inflation. Therefore, if food inflation can be controlled effectively then, overall inflation would also be managed effectively.

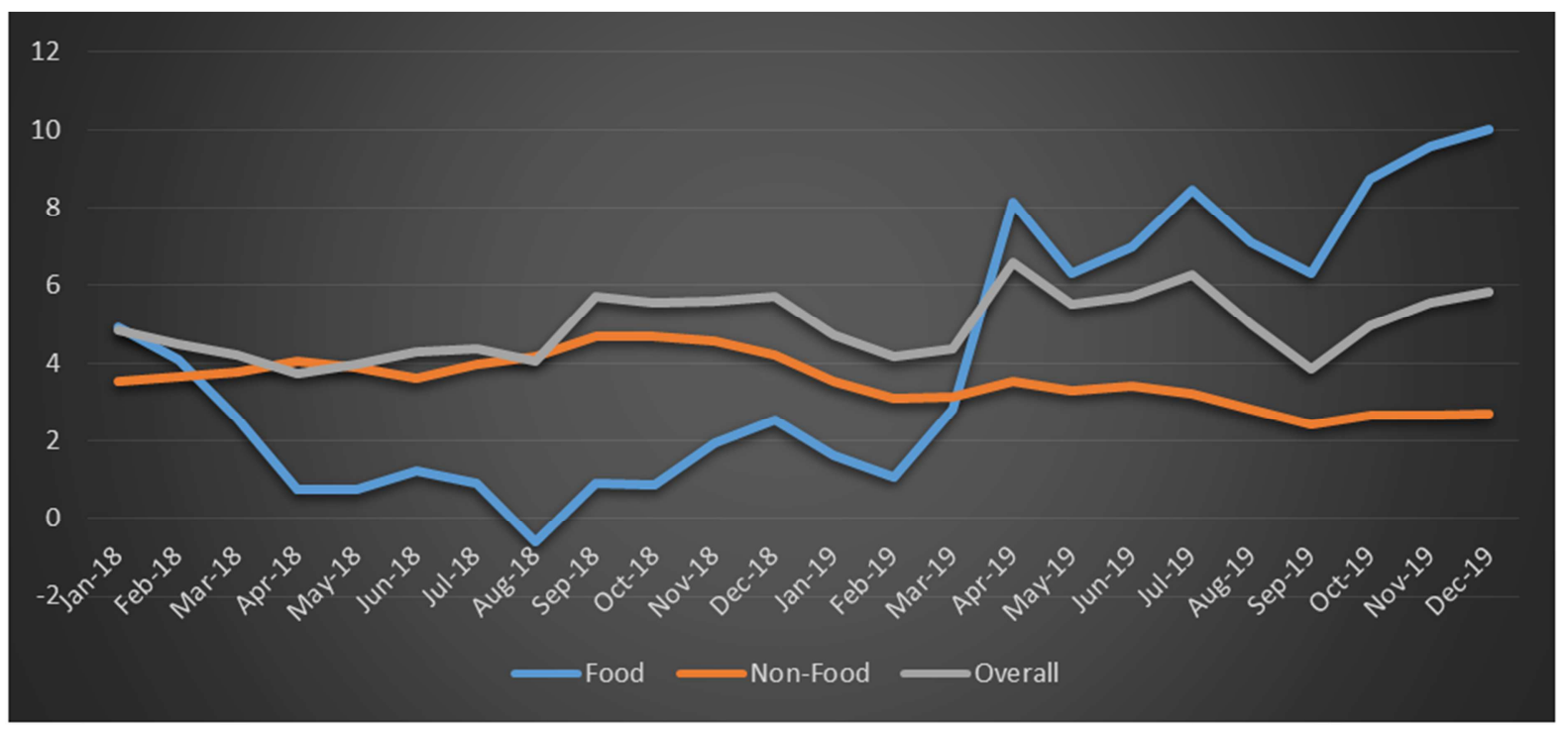

Figure 3. Food vs Non-Food Inflation Movement Source: KNBS.

\subsection{Motivation}

This paper is motivated by [10] anecdotal view that with food inflation becoming increasingly persistent and broadbased, there is need to identify factors that are driving the rapid increase in food prices. It is additionally motivated Ben Bernanke (then chairman of the US Federal Reserve) in 2008, as cited by [11] in the following quote:

"Rapidly rising prices for globally traded commodities have been a major source of relatively high rates of inflation we have been experiencing in recent years, underscoring the importance for policy of both forecasting price changes and understanding the factors that drive those changes"

The World Bank found that 35.6 percent of the Kenyan Population live in poverty and mostly affected by agricultural sector [12]. This means that, food prices if not checked, can easily lead to more population being declared as leaving below poverty line. This is also attributed by [13] who argues that if world food prices remain high and the government decides to increase domestic prices to international prices, safety nets will be required for the most vulnerable households as they will not be able to sustain their livelihood. Findings from the study by [14] also confirm that increased food prices ranging between 10 to 30 percent affects increase in overall poverty up to 12 percentage points with food poverty alone increasing up to 20 percentage points as a result of the food price rise ranging from 10 percent to 30 percent.

Although, food production is affected by weather conditions including rain patterns, fiscal and monetary policies, foreign exchange could pile pressure on food imports through trade volumes. In addition, the debate surrounding international trade has received mixed reaction since the seminal paper published by [15] which found that there exists a strong negative relationship between trade openness and inflation. Therefore, as much as Kenya inflation targets resonates around the set bounds, this study is geared towards examining if crude oil prices and trade openness has an effect on food inflation in Kenya and if it conforms to the Romer hypothesis.

\subsection{Specific Objectives}

i. Analyze the effect of Trade Openness on food Inflation in Kenya

ii. Establish the effect Crude Oil Prices on food Inflation in Kenya.

\subsection{Value of the Study}

Inflation and particularly food inflation, is something that is close to the hearts of many individuals as it affects their daily 
life. Therefore, this study will not only be important to Monetary Policy makers and academicians Scholars but the public as well. The public will particularly gain knowledge and learn how to plan their finances depending on the trends on crude oil prices and the government trade levels with international partners. Policy makers will get insights on how to stabilize food inflation and inflation through effective and reliable policy instrument in general in the context of international trade and volatility crude oil prices. Scholars and academicians will benefit from the additional body of knowledge and literature to enhance their teaching and further research in the same area of study or wider perspective.

\section{Literature Review}

It is believed that decline in crude oil prices on the international market have a direct and significant effect on the inflation of any country [16-18]. On the other hand, the debate surrounding trade openness and inflation is still inconclusive. One arm has found that trade openness positively affect inflation [19], while the other arm found the opposite $[15,20]$ and others found mixed results and others no significant relationship [21-23]. Studies below will provide an overview about the study variables in this study.

In the seminal paper by [15] study findings showed that there is a strong negative relationship between trade openness and inflation. Equally, [24] studied the relationship between trade openness and inflation. Their study centered around OECD countries and emerging economies as well. Their study finding revealed that countries with increased trade openness have larger reductions in inflation volatility in both OECD and emerging economies, but the relationship was weaker in OECD countries. [25] found a negative and significant relationship between trade openness and inflation but no relationship was found between them in the short run.

However, [20] studied the effects of trade openness and inflation in Sub-Saharan Africa and found that a negative relationship. This means that increase in trade openness tends to restrict inflation. On the other hand, [26] examined the impact of trade openness from a different perspective. They used studied impact of Free Trade Agreements (FTA) on inflation. By defining FTA as a share of trade with countries that have signed the FTA among, their study encompassed the 34 OECD countries. Their study findings showed that FTAs have a negative and significant influence on inflation hence agreeing with the Romer hypothesis.

Watson [19] examined the impact of Trade openness and inflation. The study employed Dynamic stochastic general equilibrium modeling (DSGE). The study findings showed that trade openness positively affects inflation. Sepehrivand and Azizi [27] studied the effect of trade openness on inflation in D-8 member countries. The study employed GMM method and their study findings showed that trade openness positively and significantly affects inflation

In order to understand the effect of Trade-threshold on inflation in Tunisia, [21] employed both linear and Nonlinear Approach in their study. The linear approach found a positive and significant relationship with inflation. However, the nonlinear approach showed that trade openness has negative and significant relationship with inflation agreeing to the Romer hypothesis

Munir et al.[22] investigated the effect of trade openness on inflation from selected Asian economies. The results revealed that there exists no significant relationship between trade openness inflation and for the economies and period under study. Equally, [23] examined effect of trade openness and market competition on inflation from OECD countries. Their study findings showed that greater market competition reduce inflation, but trade openness had no significant influence on inflation.

Using Producer price index as a proxy for inflation, [16] employed Johansen co-integration approach to test the effect of crude oil price on inflation in Pakistan to measure. The author used Effective exchange rate, Interest rate and Karachi Stock Exchange 100 Index (KSE-100Index) as control variables. The results of this study showed an inverse relationship exists between crude oil price and inflation.

In India, [10] investigated the causes of food inflation using Structural Vector Autoregression (SVAR) framework. The authors used monthly data with from July 1995 to September 2014. They also considered the dynamic inter-linkages among the macroeconomic indicators in their model. Their key findings showed that widening gap between demand and supply of major food groups contributed significantly to food inflation. However, fuel prices only impacted on food prices moderately. Of great importance, in this research is the fact that there exists a significant evidence of transmission of food inflation to non-food inflation and aggregate inflation with persistent effects which take long time to die out.

Oil price pass-through into inflation using traditional Phillips curve to derive estimates was examined in Kenya by [18]. The author employed data from 1967 to 2008. Research findings showed that changes in oil prices, exchange rate changes and changes in aggregate demand have had significant effects on inflation. On the same breath, [3] analyzed food inflation trends in Sub-Saharan Africa (SSA) from 2000 to 2016 with a view of establishing its causes and why it was high and persistent. Authors used monthly data and employed OLS regression. Their results showed that there exists a pass-through effect to domestic food inflation from world food inflation, fuel inflation, and exchange rate depreciation. Particularly for Kenya only Exchange rate pass through was significant.

In South Africa, [11] analyzed food inflation with a motive to identify and quantify the key fundamental factors that impact food inflation. The author employed Non-Linear Auto Regressive Distributed Lag Model (NARDL) with data period from January 2002 to September 2016. The author findings showed that local and global commodity prices and the exchange rate are the key drivers of food inflation in South Africa. Specifically, the results indicated that exchange rate and local agricultural prices have the largest impact on food inflation in South Africa, but world prices are slow to manifest in food inflation. 
The dynamic relationship between global oil price and South Africa's food price has also been examined by [17] using monthly data from 2000: 1 to 2014: 6. The author employed full sample bootstrap Granger causality tests and bootstrap rolling window tests (a time varying causality test) with fixed sample size. The findings showed mixed results using different methods. While Granger causality tests showed that oil price has no predictive power for food price, Full VAR parameter stability tests showed that both oil price and food price equations are unstable. On the other hand, the bootstrap rolling window estimation results showed that from an econometric perspective there is causal relationship between oil price and food price which is episodic, nonlinear and time varying.

Additionally, [28] analyzed the main drivers of inflation in Ethiopia and Kenya using monthly data from 2000 to 2011. The authors employed Error correction model and the Johansen cointegration approach to test for long-run relationships. Their findings indicate that World food price increases, measured in domestic currency is a key driver to inflation in both economies. They also found that Domestic food supply shocks are clearly important in Ethiopia but not strong in Kenya. This is largely due to high level of harvests which reduce inflation through its effect on domestic food prices. For the variable related to this study they find that the link between domestic and international energy prices on inflation is weak and attribute this to market interventions and imperfect competition. However, they found contradictory results to the recent studies by [29] and [30].

Inflation dynamics in selected East African countries (Ethiopia, Kenya, Tanzania and Uganda) has been investigated by [31]. Their findings showed that oil prices are the main driver of short-run inflation accounting up to one fifth and one quarter in Kenya and Tanzania respectively. However, the researchers argued that expansionary monetary policies do play an important role in these two economies to tame inflation. The other finding specific to Kenya was that exchange rate depreciation explains close to 17 percent of the observed inflation. These results agree with that of [32] and [30] as cited by [28] who also analyzed drivers of inflation in Kenya using GDP, money supply, fiscal expenditure and exchange and interest rates and found that Broad Money supply (M3) is the main driver of prices. However, [33] found an insignificant relationship between money supply and inflation in Nigeria.

From the literature above we find that no study specifically tackles food inflation explicitly despite most the studies agreeing that food prices contribute largely to inflation. This study therefore fills this gap and explores the drivers of food inflation, which if handled properly through policy intervention would assist in controlling not only food prices but the overall consumer price index basket.

\section{Data and Methodology}

\subsection{Data and Research Variables}

Monthly data spanning the period of January 2009 to December 2019 for the following variables will be used in this study: Food Consumer Price Index (CPIF); and Crude Oil prices, Trade Openness represented by Volume of trade (\% GDP); Broad Money Supply (M2) and Foreign exchange rates. Data was retrieved Central Bank of Kenya (CBK) Monthly Economic Reviews and supplemented by Kenya National Bureau of Statistics (KNBS) statistical abstracts and Leading economic Indicators. All variables except trade openness were expressed in logarithmic forms.

The mathematical model is specified in equation 1 as follows:

$$
C P I F=f(C O P, T O)
$$

Where CPIF is food inflation, COP represent Crude oil prices and TO is for Trade Openness (proxied by Imports plus exports divided by Gross Domestic Product). The model will include three control variables for the benefit of making the model robust and to capture for domestic factors like Monetary policy will be proxied by Money Supply (M2) and Foreign Exchange (FX) proxied Foreign exchange Value of KES to USD. Therefore, an econometric model will take the form as indicated in equation 2 .

$$
C P I F=\alpha_{0}+\alpha_{1} C O P+\alpha_{2} T O+\alpha_{3} \ln M 2+\alpha_{4} F X+\epsilon
$$

Where, $\alpha_{0}$ is a constant and $\alpha_{1}, \alpha_{2}, \alpha_{3}, \alpha_{4}$, represent coefficients of independent variables explained above. Finally, $\epsilon$ is the regression error term which is assumed to be normally distributed with zero mean and constant

\subsection{Estimation and Analytical Method}

This study employs Autoregressive Distributed Lag (ARDL) Model developed by [34] to estimate the long run and short effects between the variables under study. All variables will first be subjected to some stationary tests using unit root test to ensure that none of the variables is integrated to order two- I (2). In other words, ARDL can be employed when the variables are integrated to either order zero-I (0); order 1- I (1) or mutually co-integrated. Some of the advantages of ARDL include its application regardless of the stationary properties of the variables in the sample. With ARDL is also possible to make inferences on longrun estimates which are not possible under other co-integration procedures. Additionally, ARDL Model can accommodate many variables as compared to Vector Autoregressive (VAR) models. Finally, ARDL is more appropriate with small sample size unlike other estimation techniques that requires large data set for validity [35]. From the study variables, the ARDL model is them formulated as equation 3 .

$$
\begin{gathered}
\Delta C P I F=\alpha_{0}+\sum_{i=1}^{n} \alpha_{1} \Delta \ln C P I F_{t-i}+\sum_{i=0}^{n} \alpha_{2} \Delta \mathrm{COP}_{t-i}+\sum_{i=0}^{n} \alpha_{3} \Delta T O_{t-i}+\sum_{i=0}^{n} \alpha_{4} \Delta \ln M 2_{t-i}+\sum_{i=0}^{n} \alpha_{5} \Delta \mathrm{FX}_{\mathrm{t}-\mathrm{i}}+ \\
\beta_{1} \ln C P I F_{t-1}+\beta_{2} C O P_{t-1}+\beta_{3} T O_{t-1}+\beta_{4} \ln M 2_{t-1}+\beta_{5} \ln F X_{t-1}
\end{gathered}
$$

Where $\ln$ represents the natural $\log$ of the variables in the model. $\Delta$ represent first difference of the variables in the is study. Is the equation's constant term. $\alpha_{1}, \alpha_{2}, \alpha_{3}, \alpha_{4}, \alpha_{5}$ represent the short run effects while $\beta_{1}, \beta_{2}, \beta_{3}, \beta_{4}, \beta_{5}$ 
represent the long run effects of the equation.

Long run effects are tested using the bound testing. The null hypothesis is that there is no long-run relationship between the variables. This implies that the null the null hypothesis in this study will be;

$H_{0}: \beta_{1}=\beta_{2}=\beta_{3}=\beta_{4}=\beta_{5}=0$ (No long-run relationship)

$H_{1}: \beta_{1} \neq \beta_{2} \neq \beta_{3} \neq \beta_{4} \neq \beta_{5} \neq 0$ (There exists long-run relationship)

According to [34], if the coefficients of the variables at I (0) at lag 1 jointly fall above the upper bound critical value, then there exists a long- run cointegration relationship among the variables, otherwise the null hypothesis is failed to be rejected. That is if F-statistics is greater that the upper bound then we reject the Null hypothesis.

Given the long-run relationship and short run effects, there exists a possibility of short run effects to bounce back to equilibrium. Therefore, the Error Correction Model (ECM equation will be given by:

$$
\Delta C P I F=\alpha_{0}+\sum_{i=1}^{n} \alpha_{1} \Delta \ln C P I F_{t-i}+\sum_{i=0}^{n} \alpha_{2} \Delta \ln C O P_{t-i}+\sum_{i=0}^{n} \alpha_{3} \Delta \ln T O_{t-i}+\sum_{i=0}^{n} \alpha_{4} \Delta \ln \mathrm{M} 2_{t-i}+\sum_{i=0}^{n} \alpha_{6} \Delta \operatorname{lnFX} \mathrm{t}_{\mathrm{t}-\mathrm{i}}+\theta E C T_{t-1}+\epsilon
$$

ECT in equation 4 implies the speed of adjustment back to long run equilibrium after a short run shock (how quickly the variables return to the long-run equilibrium).

After estimating the equations, the next stage is to carry out diagnostic tests to check on the validity and adequacy of the model. Serial correlation, normality and heteroscedasticity tests are the test that will be carried out. In addition, as suggested by [34] stability test must be checked and therefore cumulative sum (CUSUM) and CUSUM of squares (CUSUMSQ) tests will be tested to check on the stability of the coefficient of the models estimated in this study.

\section{Empirical Results and Discussions}

\subsection{Unit Root and Cointegration}

Before carrying out the regression analysis it is expected that all data variables are stationary. Since most economic data are non-stationarity failure to test for stationarity can lead to spurious regressions problem can lead to both bias and mistaken inference [36]. This study employed
Augmented Dickey Fuller (ADF) stationary testing methods. Table 1 presents the results from the variables unit-root data tests. The results reveal that the null hypothesis of unit root is rejected at the level form for Trade Openness (TO). However, all other variables food inflation CPIF, Money supply (M2) and Foreign Exchange (FX), the null hypothesis cannot be rejected at level form. All variables are stationary after the first the first difference. Therefore, all variables are either integrated at I (O) and I (1) and hence all variables meet the conditions that allows the use of Autoregressive Distributed Lag (ARDL) model as suggested by [34].

The ADF Test also confirmed that no variable is integrated at order two I (2). The next step is to is now test for bound testing or existence of long run relationship among the variables. Existence of long run relationship was tested using cointegration tests and the results displayed in Table 2. Since the computed F-statistics of 5.22 is greater that the upper bound ( $\mathrm{F}>$ Upper Bound Value) at all levels, the result indicates rejection of the null hypothesis of no cointegration among the variables under study.

Table 1. Unit Root Test Results.

\begin{tabular}{|c|c|c|c|c|c|c|}
\hline \multirow{2}{*}{ Variable } & \multicolumn{3}{|l|}{ Level } & \multicolumn{3}{|c|}{ First Difference } \\
\hline & t-stat & P-value & Remarks & t-statistic & P-value & Remarks \\
\hline LCPIF & 13.6452 & 0.1589 & NS & $-6.5651 * * *$ & 0.0000 & $\mathrm{~S}$ \\
\hline LCPIT & -1.2606 & 0.1229 & NS & $-6.5651 * * *$ & 0.0000 & $\mathrm{~S}$ \\
\hline LCOP & -2.2378 & 0.0526 & NS & $-9.0601 * * *$ & 0.0000 & $\mathrm{~S}$ \\
\hline TO & -5.4495 & 0.0000 & $\mathrm{~S}$ & $-20.4627 * * *$ & 0.0000 & $\mathrm{~S}$ \\
\hline LM2 & $-0.5386^{* * *}$ & 0.0007 & NS & $-14.3237 * * *$ & 0.0000 & $\mathrm{~S}$ \\
\hline LFX & -1.8843 & 0.1652 & NS & $-7.9306 * * *$ & 0.0000 & $\mathrm{~S}$ \\
\hline
\end{tabular}

*** denote a rejection of the null hypothesis of nonstationary at the $1 \%$ level of significance. NS mean Nonstationary while S means stationary

At 5\% level of significance, the empirical results indicate that there exists a long run relationship between Food inflation, Crude oil prices, Trade openness, Money supply and Foreign exchange rates.

Table 2. ARDL Bound Testing for Cointegration Results.

\begin{tabular}{lll}
\hline Variables & F-Statistics \\
\hline F (CPIF, COP, TO, MS, FX) & $\mathbf{5 . 2 2 3 2 9 7 *}$ \\
\hline Critical Value & Lower Bound & Upper Bound \\
\hline $1 \%$ & 3.29 & 4.37 \\
$5 \%$ & 2.56 & 3.49 \\
$10 \%$ & 2.20 & 3.09 \\
\hline
\end{tabular}

* denote statistical significance at $5 \%$ level

\subsection{Bound Testing and Long Run Relationship}

This study employed the Johansen and Juselius cointegration approach for testing long run relationship among the study variables under study. The findings of the ARDL model in Table 3 indicate that Trade openness negatively affects food inflation in Kenya in the long run. From the findings, 1\% increase in Trade Openness will lead to reduce food inflation in Kenya by $0.55 \%$. These results agree with the study findings by [15] whose results elicited the debate around trade and inflation and those of [20] who found a negative relationship between Trade Openness and inflation in Sub-Saharan Africa. 
Considering that Kenya is a net importer, this findings could be attributed to Kenya is have a good bargaining power on it imports or engaged in trade partners who have Free trade agreements and hence enjoying the benefits of regulated tariffs, taxes and or the imports are associated with increased investments in the country hence reducing costs related to food production. However, results of this study do not conform to the findings by [19] and [27] who found a positive relationship between Trade Openness and inflation.

Regarding Crude oil prices, the long run equation indicates that Crude oil prices has as positive and significant effect on food inflation in the long. From the results, the coefficient of Crude oil prices indicates that $1 \%$ increase in price of crude oil prices per barrel increases inflation by $0.12 \%$. These results conform to the findings by $[10,17,18]$ but differed with the findings of [16]. This could be attributed to the fact that oil is a major input in any economy. Therefore, activities related to food production for example transportation costs, production of food packaging products are affected directly and hence all the associated shock spillover to the food prices.

Table 3. Long Run Estimation Results.

\begin{tabular}{lllll}
\hline Variable & Estimate & Std. Error & t-statistic & P-value \\
\hline Intercept & 7.6781 & 0.7158 & -10.7269 & 0.0000 \\
LCOP & 0.1228 & 0.0440 & 2.7935 & 0.0061 \\
TO & -0.5510 & 0.2334 & -2.3606 & 0.0199 \\
LMS & 0.5454 & 0.0592 & 9.2078 & 0.0503 \\
LFX & 1.0519 & 0.2720 & 3.8671 & 0.0002 \\
\hline
\end{tabular}

Foreign exchange rate positively affects food inflation in Kenya. Specially $1 \%$ increase in the exchange rate between Kenya shilling and the dollar leads to increase in food inflation by $1.05 \%$. These findings confirm to the findings by [37] and [38]. This could be attributed to either imported inflation through expensive imported goods (food directly or food processing materials or packaging material). In addition, foreign exchange induced food inflation could be attributed to demand push to domestic food consumption.

Money supply as expected increase food inflation. 1\% increase in money supply increases food inflation by $0.55 \%$. The effect of money supply on food inflation does not conform with results of many studies including [30] and [32] However, this study agrees with the findings of [28] from the long run approach. These results therefore fail to agree with the monetarist view that increase in money supply influencing inflation in the long run. This study therefore finds that inflation in Kenya cannot be solely be controlled through money supply.

\subsection{Short Run Relationship}

Table 4 show the estimates of the short run model from the variables under study. The results indicate that crude oil prices change positively and significantly affects food inflation in Kenya. Specifically, $1 \%$ increase in the price of crude oil per barrel increases food inflation by $0.03 \%$. This study findings agree with the findings of [18] and [on the effect of crude oil prices on inflation in the short run. Interestingly, while the relationship between trade openness and food inflation was negative and significant in the long run, the short run model found no relationship between the trade. These results conform to [25] but fails to agree to the [15] hypothesis from the short run approach. The effect of foreign exchange on food inflation is mixed in the short run with inflation being positively affected by depreciation of the Kenyan shilling but the effect is insignificant. However, the effect is negative and significant after one-month lag. This negative effect could be attributed to the short-term correction of food prices impacted by other macro-economic factors like import prices

Table 4. Short Run Estimation Model.

\begin{tabular}{lllll}
\hline & Estimate & Std. Error & t-statistic & P-value \\
\hline D (CPIF (-1)) & 0.4979 & 0.0671 & 7.4240 & 0.0000 \\
D (LCOP) & 0.0271 & 0.0124 & 2.1870 & 0.0307 \\
D (TO) & -0.0160 & 0.0221 & -0.7240 & 0.4706 \\
D (TO (-1)) & 0.0347 & 0.0221 & 1.5660 & 0.1199 \\
D (LMS) & 0.0590 & 0.0695 & 0.8490 & 0.3976 \\
D (LFEX) & 0.0858 & 0.0666 & 1.2890 & 0.1999 \\
D (LFEX (-1)) & -0.1407 & 0.0692 & -2.0340 & 0.0441 \\
ECT & -0.1211 & 0.0212 & -5.7170 & 0.0000 \\
\hline
\end{tabular}

Residual standard error: 0.01111 on 122 degrees of freedom

Multiple R-squared: 0.5317, Adjusted R-squared: 0.501

F-statistic: 17.32 on 8 and 122 DF, p-value: $<2.2 \mathrm{e}-16$

The short run model also points out that money supply has an insignificant positive impact on food inflation. These results agree with the results from the study of [33] in short run who found that money supply does not significantly influence inflation. However, the results of this study disagree with the results of [30] and [32] who posit that money supply is the key driver of inflation.

Based on the results indicated in Table 4, the estimated coefficient of the ECT term is -0.12. Since the error correction term is negative and significant, this implies that the results support the existence of a long run food inflation and the independent variables. The ECM term of -0.12 means that the speed of adjustment towards long run equilibrium is $12 \%$. between the variables. The adjusted $R^{2}$ is 0.50 indicating that the independent variables only explain $50 \%$ variation in food inflation. Therefore, there could other factors other than Trade openness; Crude oil prices; Money supply and foreign exchange that explain changes in food inflation.

\subsection{Diagnostic Checks}

Serial correlation and heteroskedasticity test were also carried out to diagnose our model and Table 5 below indicate the findings the of the diagnostic test. Breusch-Godfrey and Breusch Pagan Godfrey test for serial-correlation and Heteroskedasticity respectively were carried out. The Breusch Godfrey test p-value (0.2484) of the F statistics is higher than 0.5 indicating lack of serial correlation problem in the data study variables. Equally, the Breusch Pagan 
Godfrey p-value (0.4433) is greater than 0.05 and hence indicating lack of Heteroskedasticity problem in the data

Table 5. Serial Correlation and Heteroskedasticity tests.

\begin{tabular}{lll}
\hline & F-statistic & P-value \\
\hline Breusch-Godfrey Serial Correlation LM Test & 1.3458 & 0.2484 \\
Heteroskedasticity Test: Breusch-Pagan & 9.9679 & 0.4433 \\
\hline
\end{tabular}

The Jarque Berra Normality showed that the residual of

Recursive CUSUM test

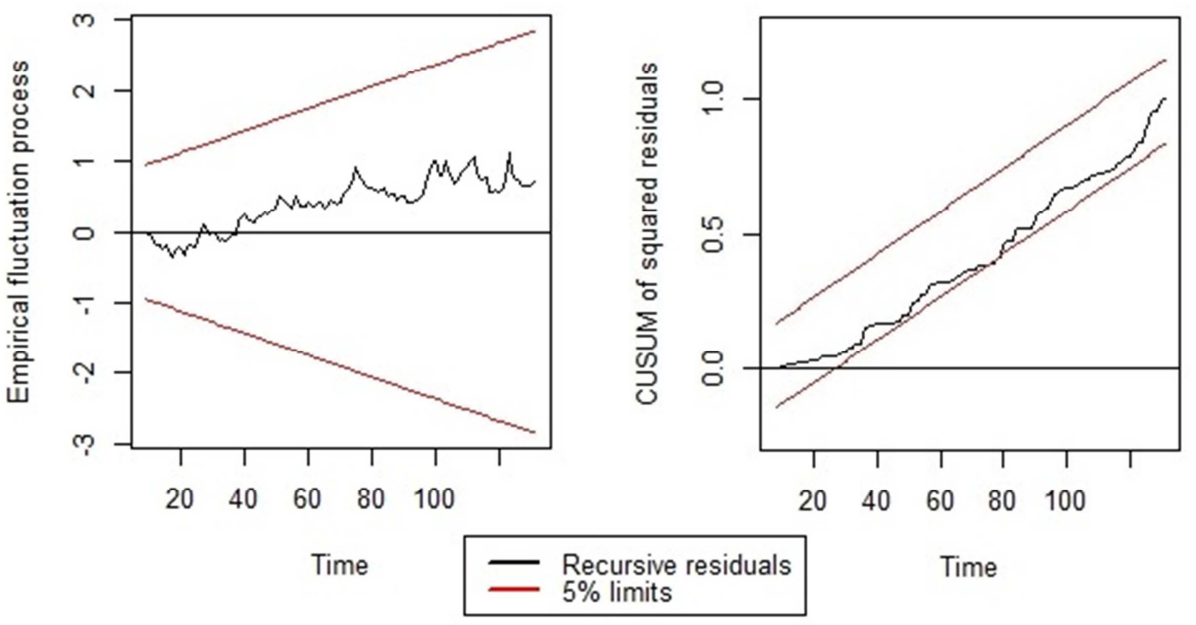

Figure 4. Stability plots.

Since the long run cointegration test confirmed existence of long run relationship, the findings indicate that there could be at least one directional causality in study model either from the short run, long run or both model estimations. Therefore, in order to confirm the direction of causality, granger causality test was performed. Since the Error Correction Term was negative and significant, it not only further confirmed the existence of long run relationship but existence of long run causality as well.

\subsection{Granger Causality Tests}

The granger causality test result shown in Table 6 indicate that there is a unidirectional causality between Crude oil price and food prices at 5\% level of significance. The direction of causation runs from crude oil prices to food inflation hence agreeing with the findings by [39] while disagreeing with findings by [40]. The causality relationship between Money supply and Food inflation is unidirectional the model is normally distributed with $\chi^{2}=4.45$ with a pvalue of 0.1027 . Stability of the model was also tested using Cumulative sum (CUSUM) and cumulative sum squares (CUSUMSQ) tests. These tests are used to confirm reliability of the long run coefficients. Figure 4 indicate both CUSUM and CUSUM squares recursive residuals remain within the critical boundaries of the 5\% significance level hence confirming the stability of the model is intact and the regression equation is stable and correctly specified.

\section{Recursive CUSUM of squares test}

with the direction of causality running from inflation to money supply at $5 \%$ level of significance. These results agree with findings by [41] and [42] who found a unidirectional causality between money supply and inflation with causality running from inflation to money supply. Equally, at 5\% level of significance, causality between Foreign exchange and food inflation is unidirectional and running from food inflation to Foreign exchange rates. However, if we consider $10 \%$ level of significance, we find a bi-directional causality between foreign exchange and food inflation. On the other hand, the study test results reveal that there is no causality between trade openness and food inflation. However, if $10 \%$ level of significance is considered, the study finds a unidirectional causality between Trade openness and food inflation. Since this study employs 5\% level of significance, therefore, the study concludes that, Trade openness does not granger cause food inflation and vice-versa in Kenya.

Table 6. Pairwise Granger Causality Test Results.

\begin{tabular}{llll}
\hline & F-statistic & P-value & Decision \\
\hline Crude Oil Price $\rightarrow$ Food Inflation & 3.7669 & 0.0446 & Reject the Null of Causality \\
Food Inflation $\rightarrow$ Crude oil Price & 0.2446 & 0.6217 & Do not Reject the Null Unidirectional \\
Trade Openness $\rightarrow$ Food Inflation & 1.7479 & 0.0802 & Do not Reject the Null \\
Food Inflation $\rightarrow$ Trade Openness & 0.0486 & 0.8259 & Do Not Reject the Null \\
Money Supply $\rightarrow$ Food Inflation & 0.0097 & 0.9216 & Do not Reject the Null No Causality \\
Food Inflation $\rightarrow$ Money Supply & 0.0052 & 0.0475 & Reject the Null \\
Foreign Exchange $\rightarrow$ Food Inflation & 2.8491 & 0.0939 & Do Not Reject the Null Unidirectional Causality \\
Food Inflation $\rightarrow$ Foreign Exchange & 4.1884 & 0.0428 & Reject the Null \\
\hline
\end{tabular}




\section{Conclusion and Policy Recommendation}

\subsection{Conclusion}

This study sought to establish the effect of Trade openness and crude oil prices on food inflation in Kenya and specifically to test if the Romer's Hypothesis hold in the Kenyan context. By applying ARDL model of estimation, the empirical findings of this study imply that, there exists a significant negative relationship between trade openness and food inflation in the long run. However, there is no relationship is found between trade openness and food inflation in the short run. In the long run view therefore, this study supports Romer's hypothesis that increase in trade openness has a reducing influence on inflation. The study also conforms to studies by [20] and [25] who had the same findings after testing Romer $\mathrm{s}$ hypothesis. This further implies that increase in international trade volumes could significantly reduce inflation. The study also found a positive and significant influence of Crude oil prices on inflation in both short run and long run approaches. This points to the importance of oil in both production and other serviceoriented aspects to the Kenyan economy. Therefore, its point to the transmission of spillovers from oil-led services like transportation and food production. However, this study finds an insignificant relationship between money supply and food inflation hence negating the monetarists view that money supply affects prices significantly. These findings do not agree with the finding of [30] and [32] who found money supply (M3) as the main driver of inflation. This could also imply that the monetary policy mechanism in Kenya is enough to control inflation and therefore money supply is not really a factor to significantly influence inflation.

\subsection{Policy Recommendation}

Findings from this study indicate that trade openness is key to the growth economy through capital flows and equally through inflation. Therefore, the Kenyan government should embrace and enhance capacity for international trade volumes while negotiating for the affordable imports and increase capacity for profitable exports. The government should also formulate polices that would encourage favorable Free Trade Agreements which would support trade volumes to the benefit of the Kenyan economy. Since trade openness has a favorable influence on inflation in Kenya, the government should explore ways of price stabilization in the long term through enhancing storage capacity and increase stocks to cushion against future decline or reduced supply in food availability or increased demand. Regarding crude oil prices, the government should formulate policies and enhance the current oil price control to further cushion oil related service and production sectors from affecting food prices. There is need to develop a mechanism and legislation to tap into improved technologies for agricultural farm production, through irrigation and reduce on rain fed agriculture and hence help in keeping food prices low.

\section{Disclaimer}

The views and opinions expressed in this publication are those of the author and do necessarily reflect the views or opinions of the United Nations.

\section{References}

[1] Qayyum, A., \& Sultana, B. (2018). Factors of food inflation: Evidence from time series of Pakistan. Journal of Banking and Finance Management, 1 (2), 23-30.

[2] Chand, R. (2010). Understanding the nature and causes of food inflation. Economic and Political Weekly, 10-13.

[3] Alper, M. E., Hobdari, M. N. A., \& Uppal, A. (2017). Food inflation in sub-Saharan Africa: causes and policy implications. International Monetary Fund

[4] KNBS, (2020): Consumer Price Indices and Inflation rates for December 2019, Nairobi, Kenya

[5] Totonchi, J. (2011). Macroeconomic theories of inflation. In International Conference on Economics and Finance Research (págs. 459-462). Singapore: IACSIT Press.

[6] Were, M., Tiriongo, S., \& Secretariat, M. P. C. (2012). Central Bank's response to economic crises from a developing African economy perspective: Lessons from Kenya's experience. Unpublished manuscript, Central Bank of Kenya, Nairobi.

[7] Aisen, A., \& Veiga, F. J. (2005). Does political instability lead to higher inflation? A panel data analysis. International Monetary Fund.

[8] Krušković, B. D., \& Maričić, T. (2014). Empirical Analysis of the Impact of Inflation Targeting on the Risk Premium. Journal of Central Banking Theory and Practice, 3 (3), 87-99.

[9] Finck, D., \& Tillmann, P. (2019). The Role of Global and Domestic Shocks for Inflation Dynamics: Evidence from Asia (No. 201904). Philipps-Universität Marburg, Faculty of Business Administration and Economics, Department of Economics (Volkswirtschaftliche Abteilung)

[10] Bhattacharya, R., \& Gupta, A. S. (2015). Food inflation in India: Causes and consequences. National Institute of Public Finance and Policy, Working Paper, (2015-151).

[11] Louw, M. (2017). An econometric analysis of food inflation in South Africa (Doctoral dissertation, University of Pretoria).

[12] World Bank.(2018). Poverty Incidence in Kenya Declined Significantly, but Unlikely to be Eradicated by 2030 . Available at https://www.worldbank.org/en/country/kenya/publication/ken ya-economic-update-poverty-incidence-in-kenya-declinedsignificantly-but-unlikely-to-be-eradicated-by-2030. Accessed on 05 January 2020.

[13] Haq, Z. U., Nazli, H., \& Meilke, K. (2008). Implications of high food prices for poverty in Pakistan. Agricultural Economics, 39, 477-484. 
[14] Shrestha, M. B., \& Chaudhary, S. K. (2012). The impact of food inflation on poverty in Nepal. NRB Economic Review, 24 (2), 1-14.

[15] Romer, D. (1993). Openness and inflation: theory and evidence. The quarterly journal of economics, 108 (4), 869903.

[16] Shafique, M. (2016). Plunging Crude Oil Prices and Its Effect on Inflation in Pakistan. Available at SSRN 2890227.

[17] Aye, G. C. (2016). Causality between Oil Price and South Africa's Food Price: Time Varying Approach. Working paper 201486, Department of Economics, University of Pretoria. Available on: file://C:/Users/u04270533/Downloads/essa_2931\% 20 (2).

[18] Kiptui, M. (2009, May). Oil price pass-through into inflation in Kenya. In African Econometric Society (AES) Conference Proceedings.

[19] Watson, A. (2016). Trade openness and inflation: The role of real and nominal price rigidities. Journal of International Money and Finance, 64, 137-169.

[20] Lin, F., Mei, D., Wang, H., \& Yao, X. (2017). Romer was right on openness and inflation: Evidence from Sub-Saharan Africa. Journal of applied economics, 20 (1), 121-140.

[21] Jedidia, K. B., Dammak, T. B., \& Kamel, H. (2019). Tradethreshold Effect on Inflation in Tunisia: New Evidence Resulting from a Nonlinear Approach. International Economic Journal, 33 (1), 149-169.

[22] Munir, S., Hasan, H., \& Muhammad, M. (2015). The effect of trade openness on inflation: Panel data estimates from selected Asian economies (1976-2010). Southeast Asian Journal of Economics, 3 (2), 23-42.

[23] Binici, M., Cheung, Y. W., \& Lai, K. S. (2012). Trade openness, market competition, and inflation: Some sectoral evidence from OECD countries. International Journal of Finance \& Economics, 17 (4), 321-336.

[24] Bowdler, C., \& Malik, A. (2017). Openness and inflation volatility: Panel data evidence. The North American Journal of Economics and Finance, 41, 57-69.

[25] Sikdar, A., Kundu, N., \& Khan, Z. S. (2013). Trade openness and inflation: A test of Romer hypothesis for Bangladesh.

[26] Kwark, N. S., \& Lim, H. (2020). Have the free trade agreements reduced inflation rates?. Economics Letters, 109054.

[27] Sepehrivand, A., \& Azizi, J. (2016). The effect of trade openness on inflation in D-8 member countries with an emphasis on Romer theory. Asian Journal of Economic Modelling, 4 (4), 162-167.

[28] Durevall, D., \& Sjö, B. (2012). The dynamics of inflation in Ethiopia and Kenya. African Development Bank Group.
[29] Were, M and Kaminchia, S. 2011. "Is Inflation Targeting Feasible in Kenya?" A paper presented at the Global Development Finance Conference, Crowne Plaza Hotel, 8th to 10th November 2011.

[30] Misati, R. N., Nyamongo, E. M., Njoroge, L. K., \& Kaminchia, S. (2012). Feasibility of inflation targeting in an emerging market: evidence from Kenya. Journal of Financial Economic Policy.

[31] Simpasa, A., Gurara, D., Shimeles, A., Vencatachellum, D., \& Ncube, M. (2011). Inflation dynamics in selected East African countries: Ethiopia, Kenya, Tanzania and Uganda. AfDB Policy Brief.

[32] Kiganda, E. O. (2014). Relationship between inflation and money supply in Kenya. Journal of Social Economics, 2 (2), 63-83.

[33] Ditimi, A., Sunday, K., \& Emma-Ebere, O. O. (2017). The upshot of money supply and inflation in Nigeria. Valahian Journal of Economic Studies, 8 (2), 75-90.

[34] Pesaran, M. H., Shin, Y., \& Smith, R. J. (2001). Bounds testing approaches to the analysis of levelrelationships. Journal of Applied Econometrics, 16 (3), 289-326

[35] Lawal, A. I., Somoye, R. O., Babajide, A. A., \& Nwanji, T. I. (2018). The effect of fiscal and monetary policies interaction on stock market performance: Evidence from Nigeria. Future Business Journal, 4 (1), 16-33.

[36] Christian, P., \& Barrett, C. B. (2018). Spurious Regressions and Panel IV Estimation: Revisiting the Causes of Conflict. The World Bank.

[37] Monfared, S. S., \& Akın, F. (2017). The Relationship Between Exchage Rates and Inflation: The Case of Iran. European Journal of Sustainable Development, 6 (4), 329-329.

[38] Helmy, O., Fayed, M., \& Hussien, K. (2018). Exchange rate pass-through to inflation in Egypt: a structural VAR approach. Review of Economics and Political Science.

[39] Malhotra, A., \& Krishna, S. (2015). The effect of Crude Oil Prices on Inflation and Interest Rates in India: Evidence from DCC-GARCH Model. Available at SSRN 2472558.

[40] Aziza, Syzdykova., Cihan, T anrioven., Symbat, Nahipbekova., \& Almaz, Kuralbayev (2019). The effects of changes in oil prices on the russian Economy. Revista ESPACIOS, 40 (14).

[41] Indalmanie, S. P. (2011). The Relationship between Money Supply and the Rate of Inflation: A Causality Approach to the Study of the Jamaican Economy, 1961-2006. Available at SSRN 2586254

[42] Emmanuel, U., Udoh, B. E., Prince, A. I., Okoh, J., \& Ndu, O. M. (2019). Money Supply and Inflation Rate in Nigeria: The Missing Link. Humanities, 7 (3), 156-166 